\title{
A Map of Kanékés and a List of Its Hamlets
}

Kanékés village (désa) lies in the Leuwidamar subdistrict (kecamatan) of the Rangkasbitung district (kabupaten) of Lebak and in the Banten province (propinsi) in west Java (see Figure 1). In this Appendix 1 I shall discuss the boundaries of Kanékés village that have been fixed and documented around 1800 and explain how I constructed the map of Figure 2. I shall present the list of 64 hamlets obtained from the Kanékés secretariat in July 2016, according to their administrative system and also in alphabetical order. As far as I know there is no new, fairly accurate map publicly available for the position of the Kanékés hamlets since the map produced by Geise (1952). Judistira Garna (1987, 1988) did not make his own maps and supplied copies of old maps by Van Tricht (1929), Koolhoven (1932) and Geise (1952). Recent books give no map at all (for instance, Kurnia and Sihabudin 2010), or the supplied map is not accurate (for instance, Erwinantu 2012). Therefore I produced a new map, by making sketches in Kanékés of the relative position of the hamlets in 2014 and 2016, and by also using the Bing and Google aerial photographs available on the Internet. This process also gave me some more understanding as regards the vulnerability of Baduy hamlets for fires: many hamlets have been moved a little and/or got another name because of a fire that entirely destroyed the hamlet.

\section{$1 \quad$ The Borders of Kanékés}

Before the beginning of the 19th century the Baduy apparently lived in a far greater area, from Cisimeut and Lebak to the Indian Ocean (Laut Kidul) in the south. Van Tricht (1929: 69) mentions that the 1929 boundaries of Kanékés had already been established at the end of the eighteenth century, and were based on agreements between the Baduy and the sultan of Banten. According to Van Tricht, these boundaries were documented by Patih Derus, an administrator in the Lebak District, in the beginning of the 19th century and later in the 19th century mentioned in a report by the inspector Spaan: 'The boundaries of Kanékés that were established by Patih Derus more than one hundred years ago are verbatim known [woordelijk bekend] to the Baduy as it is the basis of their independent existence'. Van Tricht (1929: 69-70) supplies the list of 69 identifications by natural objects (the start and finish being the same) that the Baduy enumerate, starting in the southeast at the origin of the Cidikit Tengah river, then along the south, west, north and east border; see Table 27 below. On the basis of these orally known boundaries the Baduy were able to convince the Dutch Indies government that 
their region should be extended, 'everywhere where it had been occupied unlawfully by the Muslim neighbours around them over the years' (Van Tricht 1929: 69).

In the beginning of the 2oth century the Dutch Indies government wanted to start rubber plantations south of Rangkasbitung. Hence it was necessary to establish which land could be used for plantations and which parts for agriculture and living of the population in this area (Garna 1987: 21). In this way the Dutch Indies government again formally determined the boundaries of Kanékés, along the lines of the boundaries established more than a century ago. See also the geological map with 24 Outer Baduy hamlets in Koolhoven (1932: 65, 70). In the beginning of 1986 these boundaries were marked by concrete poles around Kanékés (Garna 1987: 21).

Kurnia and Sihabudin (2010: 58-62) present a list of the present natural objects marking the boundaries of Kanékés as determined in the 198 os by the Badan Pertanahan Nasional (BPN, National Cadastral Bureau). They report that these boundaries are enumerated in the 2002 decision 'to establish the detailed borders [concerning] the collective land rights of the indigenous community of the Baduy in Kanékés village, Leuwidamar District, Lebak region dated 16 July 2002' by the district head (bupati) of Lebak. ${ }^{1}$ Comparing this 2002 list with the less detailed one presented by Van Tricht in 1929, shows that the borders of Kanékés have been very stable since the beginning of the 19th century. These lists are also consistent with the Baduy's description of the borders as given by Garna (1988: 412). However, Garna's list of natural objects runs counter-clockwise: from the southeast (starting point Hulu Ciburalang, Hulu Cidikit Tengah) to the north, west and south. The listings in Van Tricht and Kurnia \& Sihabudin are both clockwise: from the same starting point at Hulu Cidikit Tengah in the southeast to the south, west, north and south again. ${ }^{2}$ A comparison of the lists in Van Tricht and Kurnia and Sihabudin is given in Table 27 below.

\section{$2 \quad$ Maps and Hamlets}

There are several maps with hamlets of Kanékés available in print. However, as mentioned, most maps are not very accurate and/or not adjusted to the present situation.

1 Surat Keputusan Bupati Lebak Nomor: 59o/kep.233/Huk/2002 tentang Penetapan Batas Batas Detail Hak Ulayat Masyarakat Adat Baduy di Desa Kanekes Kecamatan Leuwidamar Kabupaten Lebak tertanggal 16 Juli 2002.

2 When playing the angklung in a secular setting, the players and dancers follow a circle in a counter-clockwise direction and when playing in a ritual setting, the clockwise direction is taken by the players (Van Zanten 1995: 533-537; see also Sections 4.2 and 6.4 above). Apparently the listing of the natural objects that constitute the border of Kanékés do not have restrictions: clockwise or counter-clockwise. 
In 2002 according to Kurnia and Sihabudin (2010: 58-62) and at the beginning of the 19th century according to Van Tricht (1929: 69-70); see also Garna 1988: 410-411.

Words for some natural objects used in the names:

\begin{tabular}{|c|c|c|c|c|c|}
\hline cepak & $\begin{array}{l}\text { flat, } \\
\text { flattened }\end{array}$ & karang & rock & ranca & swamp, morass \\
\hline curug & waterfall & leuwi & $\begin{array}{l}\text { deep part in a } \\
\text { river }\end{array}$ & $\begin{array}{l}\text { sirah, } \\
\text { hulu }\end{array}$ & $\begin{array}{l}\text { source, origin of } \\
\text { river }\end{array}$ \\
\hline guha & cave & $\begin{array}{l}\text { muhara, } \\
\text { muara }\end{array}$ & mouth of river & tanjakan & slope \\
\hline gunung & mountain & pasir & $\begin{array}{l}\text { hill, small } \\
\text { mountain }\end{array}$ & & \\
\hline $\begin{array}{l}\text { hulu, } \\
\text { sirah }\end{array}$ & $\begin{array}{l}\text { origin } \\
\text { of river, } \\
\text { source }\end{array}$ & pental & $\begin{array}{l}\text { spread out, fallen } \\
\text { in a sprawling } \\
\text { position (?) }\end{array}$ & & \\
\hline
\end{tabular}
1. Pasir Lumao
2. Pasir Seuhang
2. Lumaok
3. Karang Kentrung
3. Pasir Seuhang
4. Karang Sendet
4. Karang Ngajajar
5. Karang Membreng
6. Kadudipray
7. Pasir Lutung
5. Pasir Lutung
8. Gunung Handeuleum
9. Guha Badak
6. Guha Badak
10. Gedeng Ranji
11. Cipinang Ading
7. Cipinang Gading
12. Muhara Cipinang Ading
13. Follow Cibarani to the north
8. (Along) Cibarani [river]
14. Go up to Muara Ciawi

1. Hulu Cidikit Tengah 
TABLE 27 Stability of boundaries of Kanékés village as marked by natural objects (cont.)

Kurnia and Sihabudin (2010: 61-2) Van Tricht (1929: 69-70)

15 To Peundeuy Gede

16. Karedok Binung

17. Tunggul Ki Sereh

18. Pasir Peuteuy

19. Sirah Cilame

20. To Lame Gede

21. Cipicung Cangked

22. To Pasir Puyuh

23. To Batu Peredah

24. To Batu Congcot

25. Go up to Gunung Bulangit Beulah

Samper

26. To Curug Cineunggeul

27. To Sumur Tapak

28. Go up to Lame Gede

29. To Cepak Pang Rereban

3o. To Ranca Bodaan

31. To Pancuran Lojor

32. Go up to Tunggul Ki Maung

33. Go down to Pental Kadu Abuy

34. To Monggor Citolok

35. To Curug Ciater

36. To Pental Angsana Gede

37. To Ki Hiang Lawang

38. To Lame Gede

39. To Muara Ciawul
9. Curug Cipanyairan

10. Leuwi Gedé

11. Pasir Limus Marin

12. Karedok Ranca Binong

13. Sirah Cilamé

14. Batu Preda (Cipicung Cangker)

15. Gunung Pasir Puyuh

16. Cadas Beunang Natah

17. (Along) Cibulangit [river]
18. Ranca Bodaan

19. Tunggul Ki Sereh Gedé

2o. Kadu Cupu

21. Lodor Saat

22. Curug Ciater
23. Pasir Baléor

24. Muara Cihaur 
TABLE 27 Stability of boundaries of Kanékés village as marked by natural objects (cont.)

Kurnia and Sihabudin (2010: 61-2) Van Tricht (1929: 69-70)

40. To Dukuh Lojor

41. To Cikahalang

42. To Kiara Ubang

25. Pasir Mangli

43. To Pangsalakan

26. Kiara Ubang

27. Pangsalakan

44. To Batu Sahulu

45. To Sirah Cibangkong

46. To Angsana Gede (Juru Tilu/3)

At 46. West: Village Parakan Beusi, District

Bojongmanik

47. Sirah Ciseel Koneng

28. Sirah Cisaél Konéng

48. To Cikadubitung

49. To Muara Cikadubitung

5o. Follow Ciujung (river) downstream

51. Then go up to Muara Cinambo

52. Follow the Cinambo (river) to the east

53. Go on to Cigoél

54. Go on to Ciboleger

55. To Sirah Cibuyur

56. To Cikaranglayang

57. Go up the Tanjakan Rokrak

58. To Batukangkot

59. To Ranca Karahkal

6o. To Gedeng Cangcaratan

61. To Cilenggor

31. Kiara Gedé

32. Binglu Haseum

33. Sirah Cibaleger Saat

34. Batu Kangkot

35. Cadas Lemprak

62. To Sumur Beunang Natah

36. Sumur Tatah

37. Pental Muncang Gedé

63. Take footpath to Pental Gunung Sarani

38. Pental Sarani

64. Go down to Sirah Ciangsana 
TABLE 27 Stability of boundaries of Kanékés village as marked by natural objects (cont.)

Kurnia and Sihabudin (2010: 61-2) Van Tricht (1929: 69-70)

65. Follow the river Cianggsana to Muara

39. (Along) Ciangsana [river]

Ciangsana

66. Go on to Cimangseuri until its mouth,

40. (Along) Cimangseurih [river]

then to Liang Lubang Sikumprung

67. Then follow the Cisimeut upstream

41. Cadas Buluh

42. (Along) Cisimeut [river]

43. Leuwi Pangangenan

44. (Along) Cisimeut [river]

68. To Muara Cibayangtung

45. Muara Cibayantung

46. (Along) Cibayantung [river]

69. Go up to Monggor Nangpelem

47. Pental Lamé Copong

70. To Cipaniktik

48. Muara Cipanitih

49. (Along) Cipanitih

71. To Cihandeong

50. (Along) Cihandeung [river]

72. To Muara Cisarogang

51. Muara Cisorogan

52. (Along) Cisorogan [river]

73. Go up at Kadu Hileud

74. By footpath to Pental Monggor Binglu

53. Muara Cikomboy

54. Peundeuy Gedé

55. (Footpath to) Karang Combong

75. To Ungkal Gedug Batu Sahulu

56. Ungkal Gedug

76. Go down to Citamiang

57. Guha Bancét

77. To Kawung Luwuk

58. Kawung Luwuk

78. To Tunggul Nangka

79. To Cukang Bungur

8o. To Guha Bancét

81. Short-cut to Cimadene

82. To Muara Ciputat

83. Go up to Gunung Leutik (triangle)

59. Gunung Leutik 
TABLE 27 Stability of boundaries of Kanékés village as marked by natural objects (cont.)

Kurnia and Sihabudin (2010: 61-2) Van Tricht (1929: 69-70)

At 83: Southeast: Village Cicalebang, District

Muncang; North: Village Karangcombong,

District Muncang; West: Village Kanékés,

District Leuwidamar

84. To Awi Ngajajar

85. To Batu Lolo

86. Shortcut to Ranca Hideung

87. To Muara Cicalebang

88. Follow the Cidikit upstream

89. Go up at Lodar Cisaat

9o. To Ranca Lolo

91. To Hulu Cisaat (Ciburalang)

92. Until Gunung Kendeng, go west

93. Tugu Perwelu (Juru Tilu)

At 93: south: Cikate Village, District Cijaku; east: Cicalebang Village, District Muncang; northwest: Kanékés Village, District

Leuwidamar

94. Go on to Gunung Pamuntuan, a top of the Kendeng mountains. Connecting to the starting point. 6o. Ranca Kiara Rangrang

61. Mental Awi Gedé

62. (Along) Cibatu Hideung

63. Muara Cibatu Hideung

64. (Along) Cidikit [river]

65. Curug Garihul

66. Parakan Piteuk
67. Muara Teluh

68. (Along) Cidikit Tengah [river]
69. Hulu Cidikit Tengah (= starting point)

Hence I decided to make my own map (Figure 2), based on the information available in 2016. The maps given by Van Tricht (1929: opposite page 72), Koolhoven (1932: 65, 70; this is a geological map) and Geise (1952: last, unnumbered page) give boundaries of Kanékés that are identical. These maps are based on the boundaries given in Table 27 and very close to a Dutch map from 1926, that was reprinted by the army of the United 
States in 1943 (U.S. Army 1943) and that covers Kanékés except for the most southern part, but just including Cikeusik. Garna (1988: 22, 138) also used maps similar to those in Van Tricht, Koolhoven and Geise.

In December 2013 I also took a picture of the map used by the administration of Kanékés. The boundaries of this map were again almost identical to the earlier mentioned ones. This map of the secretariat was probably based on the map made by the National Cadastral Bureau (Badan Pertanahan Nasional, BPN) around 1985 that was mentioned above. Hence I trusted that I could take the boundaries of the village according to these maps by Van Tricht, Koolhoven and Geise. ${ }^{3}$

Hence in my map the boundaries of Kanékés are the same as those published by Geise (1952) and Koolhoven (1932). Then I put the different hamlets (lembur, ampian, ampéan; Indonesian: kampung), as listed below, in position. ${ }^{4}$ For several reasons that was more difficult: in the different sources there is conflicting information about the name and position of hamlets. Moreover, in the 1980s the Lebak regency introduced its own administrative system for Kanékés with three 'blocks' that each included one of the Inner Baduy hamlets: Cikeusik, Cikartawana and Cibéo. Like for other villages and towns in West Java, these 'blocks' were divided into smaller units RW (Rukun Warga: community groups) that consist of several RT (Rukun Tetangga: neighbourhood groups; see Garna 1987: 21-2). This administrative system is now also used by the present secretariat of Kanékés. In practice this means that mostly one hamlet forms just one RT and one RW consists of three to six hamlets. In Table 29 below the hamlets have been listed according to the administrative system as used by the village secretariat in July 2016.

The satellite photographs available on the Internet ${ }^{5}$ were useful for marking the position of lake Dan(g)dang Ageung and the hamlets on my map. This was combined with my knowledge of the position of the Outer Baduy hamlets obtained by walking through Kanékés. The results may be found in Figure 2. As both hamlets and rivers very often use the prefix 'Ci' (from cai, water) I have underlined the names of rivers and tributaries and printed them in blue, like the rivers themselves; the names for the hamlets are all printed in black.

3 It was interesting that the village administration initially had produced a map with many details on it. When the Baduy leaders saw this map, they asked for removal of most that information. The adjusted map that we saw on the wall of the secretarial office had less than ten of the about sixty hamlets on it; however, the three Inner Baduy hamlets Cibéo, Cikartawana and Cikeusik were included.

4 Lists of hamlets in Kanékés were obtained from the secretary Sapin in June 2014 and from the secretariat's scheme on public notice boards at the secretariat and the house of the secular village head in July 2016.

5 In particular I used the Bing maps on http://www.bing.com/maps/?FORM=Z9LH4, section Indonesia-Banten-Lebak-Ciboleger, and the Google maps like https://www.google.com/ maps/@-6.5979083,106.2280043,1709m/data=!3m1!1e3. [Last access 19 December 2018.] 
One of the major problems of making an updated map was the change of names of several hamlets. For instance, the following names of hamlets on the map in Geise (1952) do not appear in the 2016 list of the village secretariat: Curugséor (or Kaduketer, according to Van Tricht 1929: after p.72), Boncérét, Cipeucang and Cipokol. Similarly, the names of hamlets Cihalang and Bojongpaok given by Koolhoven (1932: 70, 65) do no longer exist. The more recent changes will be discussed below.

Over time some hamlets have moved to a different place, mostly because there had been a fire that destroyed the whole hamlet or the greater part of it. Erwinantu (2012: 71) mentions that Cibéo was entirely burnt twice and that then its position was moved. On 2 June 2014 the father of the village head Daénah and his neighbour in hamlet Cikadu Lebak told that during their lifetime the neighbouring hamlet Cikadu Pasir was burnt twice. Hence it was first moved and after the second fire rebuilt again on its present place. From 8 to 9 August 1993 I paid a short visit to Kanékés and stayed in the newly built official residence of the secular village head (jaro pamaréntah) Asrab in Kaduketug. ${ }^{6}$ I was then told by Asrab that on 6 August that year $5^{1}$ houses in Cikeusik burnt down and only the house of the spiritual leader (puun) had been saved. Similarly Kaduketug Gedé (113 houses and also the rice barns) was entirely burnt on 16 October 2009; ${ }^{7}$ this was also confirmed by the secular village head Daénah in 2013. The most recent big fire was in Cisaban 2 on 23 May 2017 and 84 houses and about 100 rice storage barns (leuit) were destroyed. It apparently started at the fireplace in one of the houses around 18:0o; none of the 365 inhabitants (of 105 families) was killed. ${ }^{8}$ On 12 September 2019 Pasir Ciri, a new babakan of Kadu Gedé, was destroyed by a fire that burnt 37 houses. There were no casualties, but a special gamelan was also destroyed in the fire (see Section 5.4). An unknown number of rice barns (leuit) had also been destroyed. From the satellite photographs we may see that for some hamlets the rice barns are clearly separated from the houses, such as in the three Inner Baduy hamlets, Cibéo, Cikartawana and Cikeusik. ${ }^{9}$ This is a precaution, so that when there is a fire the rice barns may be saved. See also Figure 59.

6 Building the official residence for the secular village head (jaro pamaréntah) was done in 1992; the hamlet now called Kaduketug 1 that grew around this residence is therefore sometimes referred to as 'Babakan Jaro'.

7 See, for instance, Internet articles of 16 October 20og: '113 Rumah Baduy Terbakar, Posko Didirikan' and 'Duh, Rumah dan Lumbung Padi Warga Baduy Terbakar' on https://regional.kompas.com/read/2009/10/16/16o21723/113 and <https://regional.kompas.com/read/2009/10/16/ 15322366/Duh> [last access 28 January 2019.]

8 Personal information from Mumu Zaénal Mutaqin, 26 May 2017. See also, for instance, https://news.detik.com/berita/d-3510126/satu-kampung-baduy-luar-kebakaran-warga-butuh-bantuan-logistik. [Last access 4 October 2020.]

9 Koorders already reported in 1864 for the three Inner Baduy hamlets that the rice barns (leuit) were placed 'not in the immediate neighbourhood' of the houses, but together near the shed where the rice is pounded. (Meinsma 1869:329). 


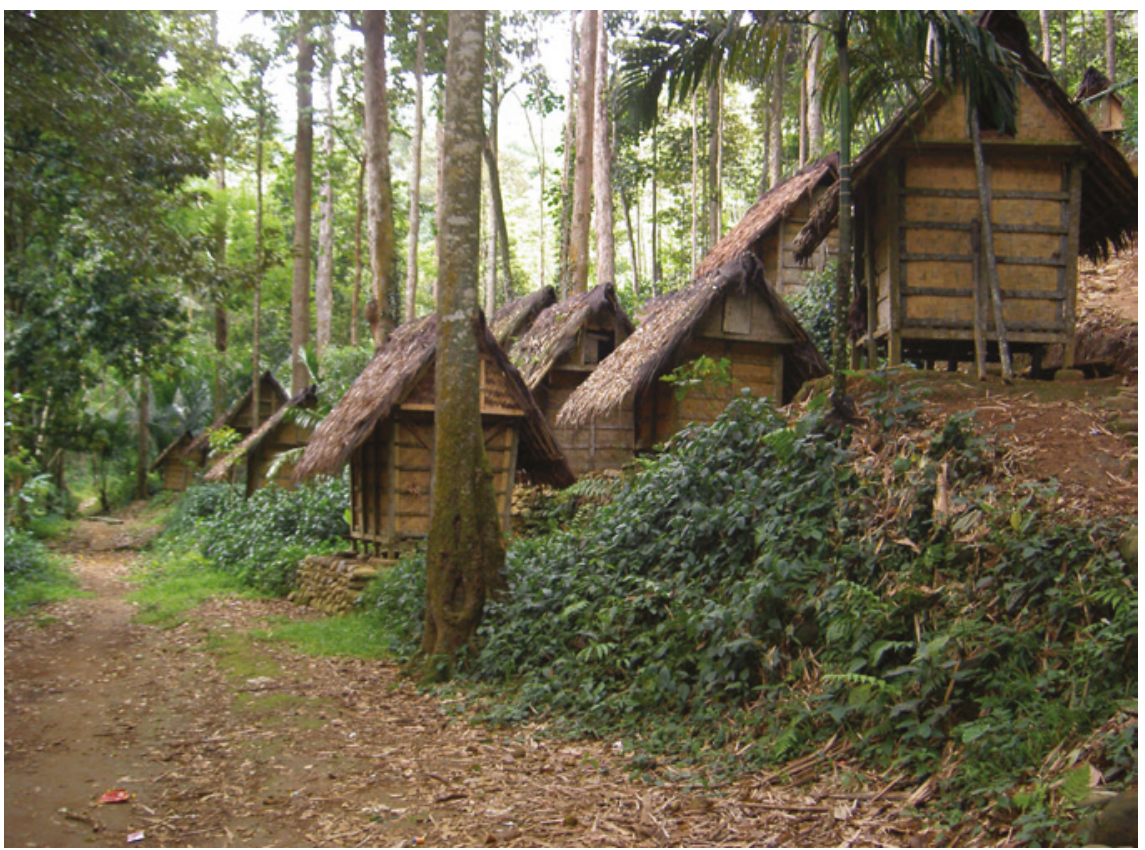

FIGURE 59 Rice barns (leuit) built across the Ciujung river and thereby separated from the houses of Gajéboh. 11 December 2013

The possible changing position and/or renaming of a hamlet was already reported by Koorders, who started his visit to the Inner Baduy area on 5 July 1864 . Under the guidance of the secular village head ('the jaro appointed by the government': jaro pamaréntah) Tarpi from Cibéo, Koorders was heading for Cisamodor: '... Cisamodor, the aim of our journey. In describing this settlement there are some characteristics that also hold for both other Baduy hamlets, Kartawana and Cibéo'. (Meinsma 1869: 328). Koorders described Cisamodor as a hamlet that was occupied six years ago, after Cikeusik had been left:

The kampung Cisamodor, they said, had been established six years ago, when the former inhabitants from the long-deserted kampung Rawayan, marked on Melvill's map of Banten, that was first moved to the presently also deserted kampung Cikeusik had settled here. The kampung has fifteen houses and "koeren" or families....

MEINSMA 1869: 330

We do not know how accurate this report was, or whether the Baduy mislead Koorders by using another name (see also Section 3.3, in particular the criticism by Jacobs and Meijer). At the moment the name Cisamodor is not used for this hamlet, but only 
TABLE 28 Different names for the three Inner Baduy hamlets from 1822-2016

\begin{tabular}{|c|c|c|c|}
\hline July 2016 & $\begin{array}{l}\text { Ritual name } \\
\text { (Geise 1952: 22; } \\
\text { Garna 1988: 232) }\end{array}$ & $\begin{array}{l}\text { Koorders (Meinsma } \\
\left.\text { 1864: } \mathbf{3}^{28}, \mathbf{3 3 0}\right)\end{array}$ & Blume (1822:31) \\
\hline
\end{tabular}

$\begin{array}{llll}\text { Cibéo } & \text { Parahiang } & \text { Cibéo } & \text { Ciboam } \\ \text { Cikartawana } & \text { Kadu Kujang } & \text { Kartawana } & \text { Kadu Kujang } \\ \text { Cikeusik } & \text { Pada Ageung } & \begin{array}{l}\text { Cisamodor, (Cikeusik, } \\ \text { Rawayan) }\end{array} & \text { Kanékés } \\ & & \text { Rayal }\end{array}$

Cikeusik or Pada Ageung. However, on the map in Geise (1952: after p 266) the name Pasir Samodo was used for a hill in Kanékés, west of Gajéboh.

Hence the names used to indicate the three tangtu hamlets have been changing over the last two centuries. Moreover there are the ritual names for these three hamlets. I have summarized this in Table 28.

Whatever happened in the past as regards the name of hamlets, also happens today. In June 2014 the secretariat listed the hamlet Cicakal Tarikkolot next to Cicakal Muara (in RW 07), like Kurnia and Sihabudin in 2010. In 2016 the name Cicakal Tarikkolot had disappeared and the secretariat had listed Cicakal Muara and Cicakal Leuwibuleud instead. I was then told that after a serious fire in Cicakal Muara the hamlet's position was slightly moved and it was then called Cicakal Tarikkolot. However, the Baduy living in that hamlet gradually moved their houses back to the old place, which was again called Cicakal Muara. Compare also Dinda S.U. Budi's report on the changes of the position of the hamlet Kampung Gedé Kasepuhan Ciptagelar, about 4okm southeast of Kanékés. This hamlet was moved because of an order (wangsit) given by the ancestors to the elders and since 1943 this happened seven times until 2015 (Budi 2015: 79-83, 103,318 ).

The hamlets or settlements (lembur, Indonesian: kampung; Jacobs and Meijer 1891: 31 used ampéan) sometimes have the same name, when they are near to each other, like Kaduketug 1 (established in 1992 and currently also called Kaduketug Jaro, with the official house of the secular village head, and bordering Cibolégér, just outside Kanékés), Cipondok (earlier also called Kaduketug 2) and Kaduketug Gedé (the oldest Kaduketug hamlet; earlier called Kaduketug 1). Other hamlets, such as the four Gajéboh hamlets, got different names right from the beginning: Gajéboh (oldest one), Balimbing or Cibalimbing (since about 1993), Maréngo (since about 1995) and Kuya or Cikuya (since about 2012). A hamlet growing next to an existing one is also called $b a$ bakan (newly established hamlet), for instance Babakan Sorokokod that is now called Ciwaringin. A group of houses becomes a hamlet, when it gets a 6 to 8 metre-long 
wooden trough in an open, roofed space (saung lesung) for the communal pounding of rice and after the official recognition ceremony by Baduy leaders (nukuh lembur; see Section 6.4) has been performed.

Like the names of the hamlets, the hills and mountains seem to change names over time. For instance, in 2014 people in Cisaban Tengah/Cisaban 2 did not know a hill Pasir Binglu that appears on Geise's map. This hill near Karangcombong, just outside Kanékés, was called Gunung Lémok by them. This is not reflected in my map in Figure 2, in which I kept the names of the hills as published by Geise in $195^{2}$.

Below I present a list of the 64 hamlets in Kanékés, including the names of the heads of RT and RW, that were registered by the secretariat of Kanékés in July 2016. These hamlet names were compared to those given by Kurnia and Sihabudin (2010: 68-71), representing the situation in January 2010. This last list is identical with the 58 hamlets mentioned in Peraturan Desa Kanékés (2007:4-5). In May 2014 there were 62 hamlets on the list of the village secretary: two less than in 2016. The hamlets Cilingsuh and Cicangkudu, listed by Kurnia and Sihabudin (2010: 69-71), no longer exist according to the village secretary Sapin and information from the inhabitants of Cikadu. I assume that on the 2016 list Cilingsuh was renamed to Cikadu Babakan and Cicangkudu was renamed Cepakhuni. Further, there were six new hamlets added between the 2010 and 2016 lists: Cepakbungur (or Cibungur, formerly called Nagrék?), Cicampaka, Ciémés, Cikuya, Ciranji Pasir and Kaduketug Kalér (see also Sapin in A2014-1: 61).

Between 2010 and 2016 several hamlets (RT) got another number or were administratively moved from one RW to another. Between June 2014 and July 2016 the overall administrative structure as supplied by the Kanékés secretariat remained fairly stable. However, 15 of the 64 RT hamlets had been given another number. Further, 6 of the 13 heads of Rw's had been replaced and 16 of the 64 heads of RT's had been replaced, or added when the hamlet was established between 2014 and 2016. In Table 29 below I also included the number of families and people living in each hamlet, as given by Kurnia and Sihabudin (2010). These figures are not consistent (and I have indicated the major inconsistences), but give a general idea about the size of a hamlet.

Not included in this list are the Kompol hamlets (Cicengal 1, Cicengal 2, Cikaréo/ Cikarého, Cirancak, and Lebak Kiara $)^{10}$ and the other dangka hamlets outside Kanékés. The resettlement hamlets dating from the resettlement projects of the 197os (Cipangembar at an old rubber plantation in Pasir Kopo, Gunung Tunggal; Margaluyu and Pal Opat; Sukatani, Jalupang Mulya village) have not been included, as the inhabitants - in contrast to the dangka hamlets - do no longer follow the Baduy rituals and are therefore no longer recognized as members of the Baduy community.

10 Erwinantu (2012: 88) gives: Kompol, Ceupakbuah, Cikaréo, and Cicengal. 
List of hamlets, with the names of the Rw head (pangiwa) and RT head and total number of RW inhabitants in July 2016 according to the village secretariat. Further the number of families and inhabitants in 2010 per hamlet after Kurnia and Sihabudin 2010: 69-71.

\begin{tabular}{|c|c|c|c|c|c|}
\hline $\begin{array}{ll}\# \quad \text { \#RW, } \\
\text { name }\end{array}$ & \#RT, name & $\begin{array}{l}\text { Hamlet or settlement } \\
\text { (lembur, ampéan } \\
\text { kampung) July } 2016 ;+ \\
\text { indicates the domicile } \\
\text { of the head of the } \mathrm{RW} \\
\text { (pangiwa) }\end{array}$ & $\begin{array}{l}\text { Total \# } \\
\text { inhabitants } \\
\text { Rw in July } \\
2016\end{array}$ & $\begin{array}{l}\# \\
\text { families } \\
2010\end{array}$ & $\begin{array}{l}\# \\
\text { inhabitants } \\
2010\end{array}$ \\
\hline
\end{tabular}

1 o1-Sajum o1-Sarman Kaduketug (1): seat jaro

46

137

pamaréntah since 1992;

present seat of dangka

Singalayang

2

o2-Sarikam Cipondok (present seat

61

$229^{a}$

of dangka Warega)

3

o3-Juned Kaduketug Gedé/

$15^{2} \quad 408$

- 2: dangka Carungan

and present seat of

dangka Sirahdayeuh

4

o4-[no Kadukaso

11

$3^{2}$

name]

o5-Sarwan Cihulu:dangka Cipatik

68

237

6

o6-Arka

+Kaduketug Kalér/

Kaduketug 3 (new)

Total number of

1033

$33^{b}$

1043

families/inhabitants in

RW 01

7 o2-Ailin o1-Pulung +Maréngo

42

180

A

o2-Ijom

Gajéboh

91

440

9

o3-Diman

Balimbing/Cibalimbing

46

212

10

04-Sarja

Cigula

41

156

o5-Pulung B Cikuya (new) 
TABLE 29 Hamlets in Kanékés arranged according to RW and RT, July 2016 (cont.)

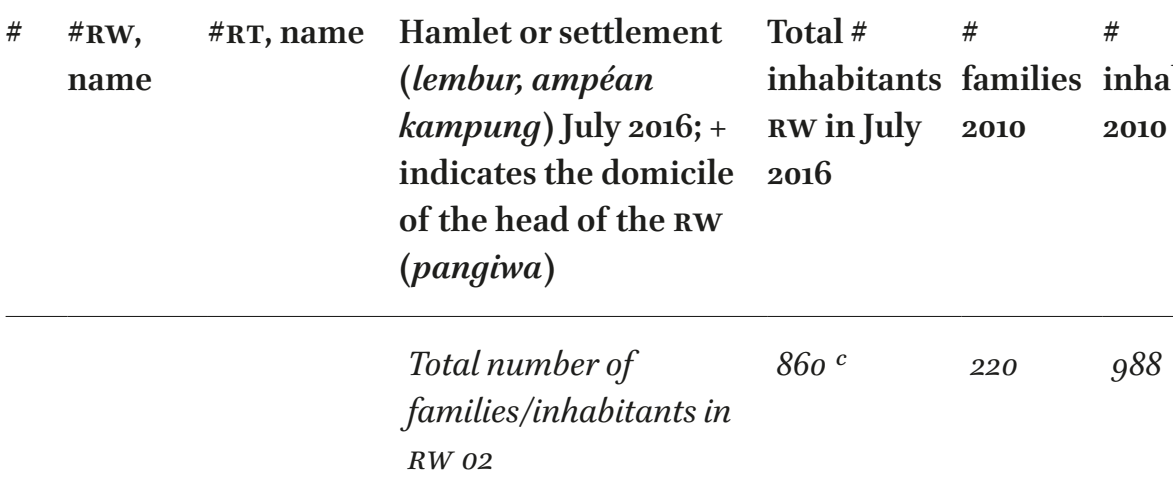

\begin{tabular}{|c|c|c|c|c|c|}
\hline o3-Su'eb & o1-Sangsang & +Kadujangkung & & 71 & 246 \\
\hline 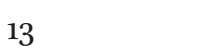 & o2-Kaisan & Karahkal & & 86 & 337 \\
\hline 4 & o3-Omo & Kadugedé & & 25 & 100 \\
\hline \multirow[t]{2}{*}{15} & o4-Mulyono & $\begin{array}{l}\text { Campaka/Cicampaka } \\
\text { (new) }\end{array}$ & & - & - \\
\hline & & $\begin{array}{l}\text { Total number of } \\
\text { families/inhabitants in } \\
R W 03\end{array}$ & $792^{d}$ & $202^{e}$ & 683 \\
\hline \multirow[t]{7}{*}{ o4-Rajak } & o1-Asdi & Kaduketer 1 & & 65 & 270 \\
\hline & o2-Caisin & +Kaduketer 2 & & 20 & 89 \\
\hline & $\begin{array}{l}\text { o3-Ayah } \\
\text { Jamah }\end{array}$ & Cicatang 1 & & 16 & 78 \\
\hline & $\begin{array}{l}\text { o4-Ayah } \\
\text { Sainah }\end{array}$ & Cicatang 2 & & 36 & 122 \\
\hline & o5-Juned & Cikopéng & & 47 & 174 \\
\hline & o6-Nasim & Cibongkok & & 14 & 47 \\
\hline & & $\begin{array}{l}\text { Total number of } \\
\text { families/inhabitants in } \\
R W 04\end{array}$ & 818 & 198 & 780 \\
\hline \multirow[t]{4}{*}{ o5-Emod } & o1-Samid & Sorokokod & & 90 & 392 \\
\hline & $\begin{array}{l}\text { O2- } \\
\text { Sangsang }\end{array}$ & Ciwaringin & & 42 & 172 \\
\hline & o3-Nalim & Cibitung & & 15 & 57 \\
\hline & o4-Jarip & Batara & & 63 & 247 \\
\hline
\end{tabular}


TABLE 29 Hamlets in Kanékés arranged according to RW and RT, July 2016 (cont.)

\begin{tabular}{|c|c|c|c|c|c|}
\hline $\begin{array}{l}\text { \#RW, } \\
\text { name }\end{array}$ & \#RT, name & $\begin{array}{l}\text { Hamlet or settlement } \\
\text { (lembur, ampéan } \\
\text { kampung) July } 2016 ;+ \\
\text { indicates the domicile } \\
\text { of the head of the RW } \\
\text { (pangiwa) }\end{array}$ & $\begin{array}{l}\text { Total \# } \\
\text { inhabitants } \\
\text { RW in July } \\
2016\end{array}$ & $\begin{array}{l}\# \\
\text { families } \\
2010\end{array}$ & $\begin{array}{l}\# \\
\text { inhabitants } \\
2010\end{array}$ \\
\hline
\end{tabular}

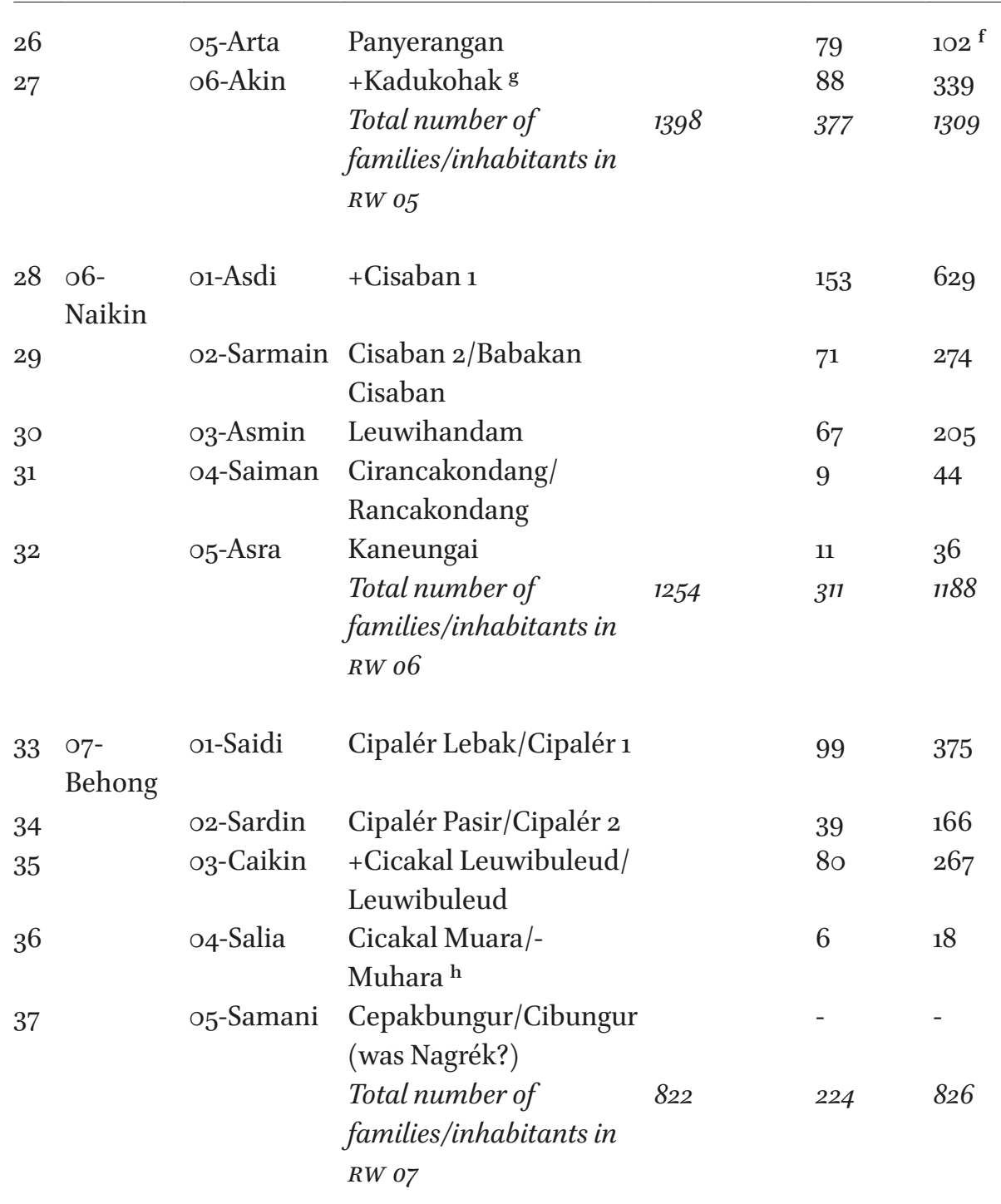


TABLE 29 Hamlets in Kanékés arranged according to RW and RT, July 2016 (cont.)

\begin{tabular}{|c|c|c|c|c|c|}
\hline $\begin{array}{l}\text { \# } \quad \text { \#RW, } \\
\text { name }\end{array}$ & \#RT, name & $\begin{array}{l}\text { Hamlet or settlement } \\
\text { (lembur, ampéan } \\
\text { kampung) July 2016; + } \\
\text { indicates the domicile } \\
\text { of the head of the RW } \\
\text { (pangiwa) }\end{array}$ & $\begin{array}{l}\text { Total \# } \\
\text { inhabitants } \\
\text { Rw in July } \\
2016\end{array}$ & $\begin{array}{l}\# \\
\text { families } \\
2010\end{array}$ & $\begin{array}{l}\# \\
\text { inhabitants } \\
2010\end{array}$ \\
\hline
\end{tabular}

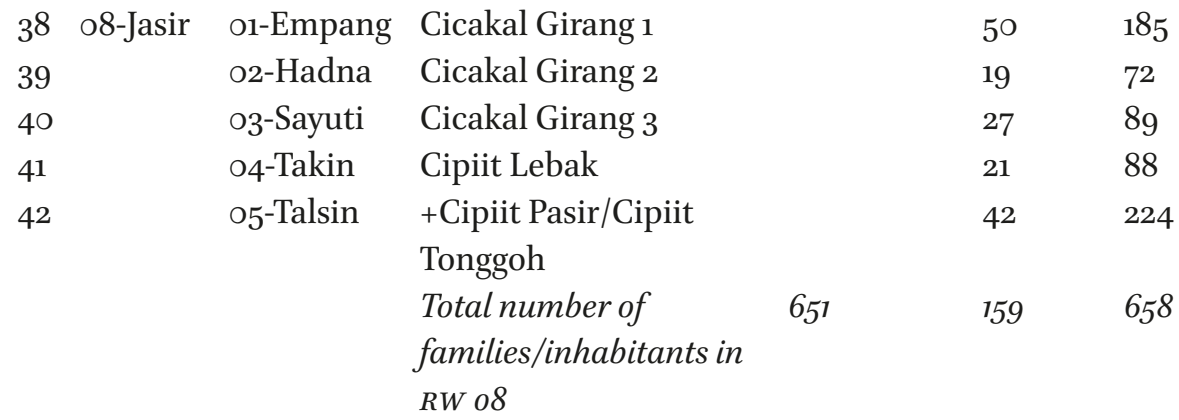

\begin{tabular}{|c|c|c|c|c|}
\hline 43 og-Taki & o1-Sarda & Cikadu Lebak & & 62 \\
\hline 44 & o2-Pulung & Cikadu Pasir & & 61 \\
\hline 45 & o3-Salim & +Cikadu Babakan ${ }^{\mathrm{i}}$ & & 16 \\
\hline 46 & o4-Aja & Cijangkar & & 7 \\
\hline 47 & o5-Naisin & Cijéngkol & & 39 \\
\hline & & $\begin{array}{l}\text { Total number of } \\
\text { families/inhabitants in } \\
R W \text { og }\end{array}$ & $617^{j}$ & 185 \\
\hline
\end{tabular}

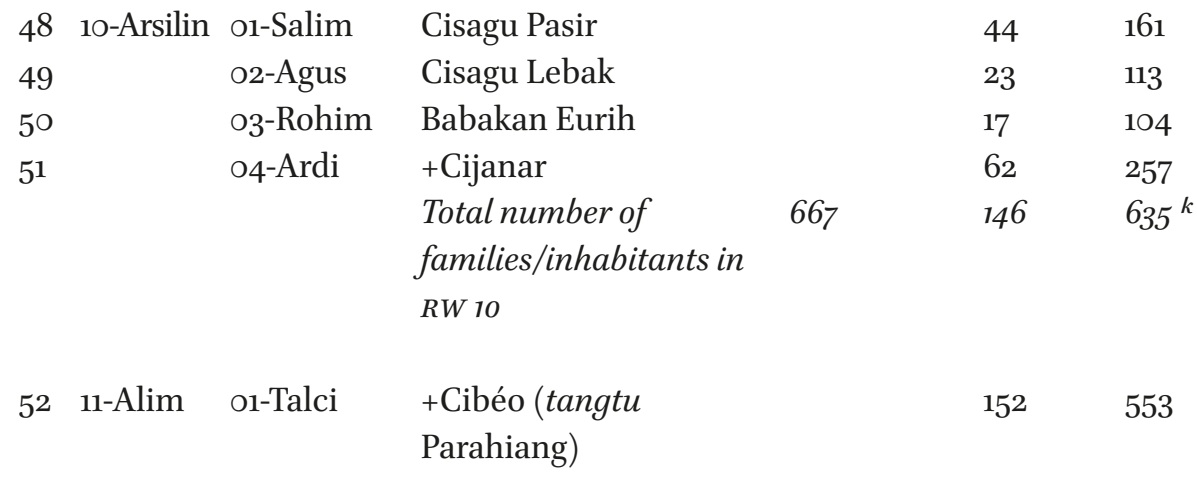


TABLE 29 Hamlets in Kanékés arranged according to RW and RT, July 2016 (cont.)

\begin{tabular}{|c|c|c|c|c|c|}
\hline $\begin{array}{l}\text { \# } \quad \begin{array}{l}\text { RW, } \\
\text { name }\end{array}\end{array}$ & \#RT, name & $\begin{array}{l}\text { Hamlet or settlement } \\
\text { (lembur, ampéan } \\
\text { kampung) July } 2016 ;+ \\
\text { indicates the domicile } \\
\text { of the head of the RW } \\
\text { (pangiwa) }\end{array}$ & $\begin{array}{l}\text { Total \# } \\
\text { inhabitants } \\
\text { RW in July } \\
2016\end{array}$ & $\begin{array}{l}\# \\
\text { families } \\
2010\end{array}$ & $\begin{array}{l}\text { \# } \\
\text { inhabitants } \\
2010\end{array}$ \\
\hline
\end{tabular}

\begin{tabular}{|c|c|c|c|c|c|}
\hline 52 & $\begin{array}{l}\text { o2-Ayah } \\
\text { Asid }\end{array}$ & $\begin{array}{l}\text { Cikeusik (tangtu Pada } \\
\text { Ageung) }\end{array}$ & & 113 & 451 \\
\hline & $\begin{array}{l}\text { o3-Ayah } \\
\text { Dalkin }\end{array}$ & $\begin{array}{l}\text { Cikartawana (tangtu } \\
\text { Kadu Kujang) }\end{array}$ & & 38 & 160 \\
\hline & & $\begin{array}{l}\text { Total number of } \\
\text { families/inhabitants in } \\
R W 11\end{array}$ & 1212 & 303 & $1164^{l}$ \\
\hline
\end{tabular}

\begin{tabular}{|c|c|c|c|c|c|}
\hline 55 12-Salim & o1-Sarim & Ciranji Lebak & & 48 & 170 \\
\hline $5^{6}$ & o2-Sarpin & +Ciranji Pasir (new) & & - & - \\
\hline 57 & o3-Asmani & $\begin{array}{l}\text { Cikuléngséng/ } \\
\text { Cikulingséng }\end{array}$ & & 13 & 49 \\
\hline 58 & $\begin{array}{l}\text { o4-[no } \\
\text { name }]\end{array}$ & Cibagelut & & 20 & 78 \\
\hline 59 & $\begin{array}{l}\text { o5-[no } \\
\text { name }]\end{array}$ & $\begin{array}{l}\text { Cepakhuni (or } \\
\text { Cicangkudu; new) }\end{array}$ & & 15 & 45 \\
\hline \multirow[t]{2}{*}{60} & o6-Atim & $\begin{array}{l}\text { Ciémés (not yet } \\
\text { formally recognized) }\end{array}$ & & - & - \\
\hline & & $\begin{array}{l}\text { Total number of } \\
\text { families/inhabitants in } \\
R W 12\end{array}$ & $619^{m}$ & 96 & 342 \\
\hline
\end{tabular}

\begin{tabular}{|c|c|c|c|c|}
\hline $61 \quad$ 13-Kemik & o1-Alcin & +Cisadané & 61 & 220 \\
\hline 62 & o2-Arji & Batubeulah & 38 & 131 \\
\hline 63 & o3-Naitim & Cibogo & 79 & 265 \\
\hline 64 & o4-Ayah & Pamoéan/Pamowéan & 48 & 19 \\
\hline
\end{tabular}

Total number of $\quad 924 \quad 226 \quad 809$

families/inhabitants in RW 13

Total in Kanékés (2010) $\quad 2985^{n} \quad 11176$ 
TABLE 29 Hamlets in Kanékés arranged according to RW and RT, July 2016 (cont.)

\begin{tabular}{|c|c|c|c|c|c|}
\hline $\begin{array}{l}\text { \# } \quad \begin{array}{l}\text { RW, } \\
\text { name }\end{array}\end{array}$ & \#RT, name & $\begin{array}{l}\text { Hamlet or settlement } \\
\text { (lembur, ampéan } \\
\text { kampung) July } 2016 ;+ \\
\text { indicates the domicile } \\
\text { of the head of the RW } \\
\text { (pangiwa) }\end{array}$ & $\begin{array}{l}\text { Total \# } \\
\text { inhabitants } \\
\text { RW in July } \\
2016\end{array}$ & $\begin{array}{l}\# \\
\text { families } \\
2010\end{array}$ & $\begin{array}{l}\text { \# } \\
\text { inhabitants } \\
2010\end{array}$ \\
\hline
\end{tabular}

Total in Kanékés (July $\quad 11667 \quad$ [3402]
2016)

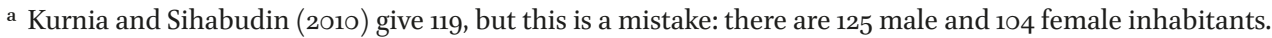

b Kurnia and Sihabudin give 302; according to the sum in RW or this number should be 338 .

c This number of inhabitants of RW 02 is 128 lower than given by Kurnia and Sihabudin in 2010. I do not know the reason for this.

d This number of inhabitants is 109 more that given by Kurnia and Sihabudin in 2010.

e Number as given in Kurnia and Sihabudin; according to the sum in RW O3, this number should be 182 .

f According to Kurnia and Sihabudin the number of inhabitants is roughly 3.7 times the number of families in a hamlet for 2010 (and 3.4 for 2016 , according to the figures of the Kanékés secretariat), so these figures for Panyerangan are presumably not accurate.

g In 2010 Kadukohak was administratively included in RW o6, and not in RW 05 as in 2014 and 2016.

h Kurnia and Sihabudin give the hamlet Cicakal Tarikkolot, which was a temporary name for Cicakal Muara, after it was destroyed by fire and moved to a different place (see above).

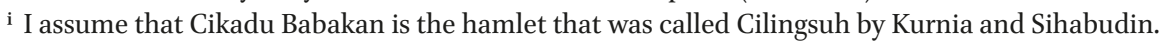

j I do not know why this number is 134 below the one given by Kurnia and Sihabudin.

k Kurnia and Sihabudin give 658; according to the sum of the inhabitants per hamlet this should be 635 .

${ }^{1}$ Kurnia and Sihabudin give 1170; according to the sum of the inhabitants per hamlet this should be 1164 .

$\mathrm{m}$ This RW 12 consists of some new hamlets and that may be the reason that the total number of inhabitants has almost doubled: from 342 in 2010 to 619 in July 2016. Ciémés is not yet officially recognized (with nukuh lembur ritual) and consisted of five houses in July 2016.

${ }^{\mathrm{n}}$ Kurnia and Sihabudin give 2948 families and 11172 inhabitants, but I presented the sum for all $\mathrm{RW}$ and the sum for all RT given in this table. For July 2016 the secretariat gave the total number of families in Kanékés as 3402 .

In Table 30 the hamlets have been listed alphabetically. For each hamlet the RT and RW were given, according to the list of the village secretary in July 2016. This 'list 2016' is slightly different from the list given in Kurnia and Sihabudin (2010: 69-71) and the earlier list supplied by the secretariat in 2014. Because the seven dangka hamlets outside Kanékés play an important role in Baduy society, these are also included in Table 3 o. 
TABLE 30 Alphabetical list of hamlets in Kanékés and the seven dangka hamlets outside Kanékés, July 2016

\section{Classification $\mathrm{RW} / \mathrm{RT}$ according to village secretariat}

\begin{tabular}{|c|c|c|c|c|c|c|c|}
\hline \# & Hamlet (alphabetical) & RW & $\mathbf{R T}$ & $\#$ & Hamlet (alphabetical) & RW & $\mathbf{R T}$ \\
\hline & $\begin{array}{l}\text { Babakan Cisaban: see } \\
\text { Cisaban } 2\end{array}$ & & & 34 & Cipalér Lebak/Cipalér 1 & O7 & $\mathrm{O} 1$ \\
\hline 1 & Babakan Eurih & 10 & o3 & 35 & Cipalér Pasir/Cipalér 2 & $\mathrm{O} 7$ & $\mathrm{O} 2$ \\
\hline 2 & Balimbing & $\mathrm{O} 2$ & $\mathrm{O} 3$ & 36 & Cipiit Lebak & o8 & $\mathrm{O} 4$ \\
\hline 3 & Batara & $\mathrm{O} 5$ & $\mathrm{O} 4$ & 37 & $\begin{array}{l}\text { Cipiit Pasir/Cipiit } \\
\text { Tonggoh }\end{array}$ & o8 & $\mathrm{O} 5$ \\
\hline 4 & Batube(u)lah & 13 & $\mathrm{O} 2$ & 38 & $\begin{array}{l}\text { Cipondok: present seat of } \\
\text { jaro dangka Warega }\end{array}$ & $\mathrm{O} 1$ & $\mathrm{O} 2$ \\
\hline 5 & $\begin{array}{l}\text { Cepakbungur/Cibungur } \\
\text { (new) }\end{array}$ & $\mathrm{O} 7$ & $\mathrm{O} 5$ & 39 & $\begin{array}{l}\text { Cirancakondang/ } \\
\text { Rancakondang }\end{array}$ & $\mathrm{O} 5$ & $\mathrm{O} 4$ \\
\hline 6 & Cepakhuni/Cicangkudu & 12 & $\mathrm{O} 5$ & 40 & Ciranji Lebak & 12 & $\mathrm{O} 1$ \\
\hline 7 & Cibagelut & 12 & 04 & 41 & Ciranji Pasir (new) & 12 & $\mathrm{O} 2$ \\
\hline & Cibalimbing: see Balimbing & & & 42 & Cisaban 1 & o6 & $\mathrm{O} 1$ \\
\hline & $\begin{array}{l}\text { Cibengkung } \\
\text { (Nangkabengkung, }\end{array}$ & - & - & 43 & $\begin{array}{l}\text { Cisaban 2/Babakan } \\
\text { Cisaban }\end{array}$ & o6 & $\mathrm{O} 2$ \\
\hline
\end{tabular}

Bengkung): dangka

Padawaras, outside Kanékés

\begin{tabular}{|c|c|c|c|c|c|c|}
\hline 8 & Cibéo (tangtu Parahiang) & 11 & $\mathrm{O} 1$ & 44 & Cisadané & 13 \\
\hline 9 & Cibitung & $\mathrm{O} 5$ & O3 & 45 & Cisagu Pasir/Cisagu 1 & 10 \\
\hline 10 & Cibogo & 13 & O3 & 46 & Cisagu Lebak/Cisagu 2 & 10 \\
\hline 11 & Cibongkok & $\mathrm{O} 4$ & o6 & 47 & Ciwaringin & 05 \\
\hline & Cibungur: see Cepakbungur & & & - & Eurih: see Babakan Eurih & - \\
\hline & $\begin{array}{l}\text { Cicakal Girang 1/Sirah } \\
\text { Cicakal } 1\end{array}$ & o8 & $\mathrm{O} 1$ & 48 & Gajéboh & $\mathrm{O} 1$ \\
\hline & $\begin{array}{l}\text { Cicakal Girang 2/Sirah } \\
\text { Cicakal 2/Babakan Cicakal }\end{array}$ & O8 & $\mathrm{O} 2$ & - & Garéhong see Cilénggor & - \\
\hline
\end{tabular}

Cicakal 2/Babakan Cicakal

Girang

14 Cicakal Girang 3

o8 $\quad 03$

49 Kadugedé

O3 $\quad 03$

50 Kadujangkung

O3 01

Muara

15 Cicakal Leuwibuleud

16 Cicakal Muara/Cicakal Hilir

$5^{1}$ Kadukaso

O1 04

$\begin{array}{ll}07 & 04\end{array}$

$5^{2}$ Kaduketer 1

0401 
TABLE 30 Alphabetical list of hamlets in Kanékés and the seven dangka hamlets outside Kanékés, July 2016 (cont.)

\section{\# Hamlet (alphabetical) $\quad$ RW $\quad$ RT $\quad$ \# Hamlet (alphabetical) $\quad$ RW $\quad$ RT}

- Cicakal

Tarikkolot: see - Muara

17 Cicampaka/Campaka (new $\quad 03 \quad 04$ hamlet)

- Cicangkudu: see Cepakhuni

18 Cicatang 1

19 Cicatang 2

20 Ciémés (not yet formally recognized)

21 Cigula

- Cihandam: dangka Sirahdayeuh a outside Kanékés

22 Cihulu: dangka Cipatik

23 Cijanar

24 Cijangkar

25 Cijéngkol

26 Cikadu Babakan (former Cilingsuh?)

27 Cikadu Pasir

28 Cikadu Lebak

$04 \quad 04$

$12 \quad 06$

O2 04
53 Kaduketer 2

$04 \quad 02$

5 Kaduketug (1): seat of

$\mathrm{O} 1 \mathrm{O1}$ jaro pamaréntah and since 2016 seat jaro dangka Singalayang

55 Kaduketug Gedé/ O1 O3

Kaduketug 2: dangka

Carungeun?; seat of jaro dangka Singalayang until 2016;

o4 $03 \quad 56$ Kaduketug Kalér/- 3: new, o1 o6 north of Kaduketug Gedé

57 Kadukohak $05 \quad 06$

Kamancing: dangka

Waréga or Sanghyang

Panunggulan outside

Kanékés

58 Kaneungai

o6 $\quad 05$

59 Karahkal

O3 02

o1 05 - Kompol: dangka

Garukgak outside

Kanékés

$10 \quad 04 \quad-\quad$ Leuwibuleud: see Cicakal

L.

$\begin{array}{llllll}09 & 04 & 60 & \text { Leuwihandam } & 06 & 03\end{array}$

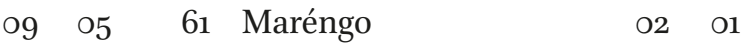

o9 03 - Nangkabenkung: see

Cibengkung

o9 $02 \quad$ - Nungkulan: dangka

Sindang Nyair outside

Kanékés

o9 $01 \quad 62$ Pamoéan/Pamowéan

$13 \quad 04$ 
TABLE 30 Alphabetical list of hamlets in Kanékés and the seven dangka hamlets outside Kanékés, July 2016 (cont.)

\# Hamlet (alphabetical) $\quad$ RW $\quad$ RT $\quad \begin{array}{lllll}\text { Hamlet (alphabetical) } & \text { RW } & \text { RT }\end{array}$

29 Cikartawana (tangtu Kadu

Kujang)

30 Cikeusik (tangtu Pada Ageung)

31 Cikopéng

32 Cikuléngséng

33 Cikuya (new hamlet)

- Cilénggor (=

Garéhong): dangka

Sanghyang Asuh outside

Kanékés

- Cilingsuh: became Cikadu

Babakan on 2016 list

- Cinangsi: on list 2010, not on

lists 2014 and 2016
$11 \quad \mathrm{O} 3$

Panyaweuhan: dangka

Inggung outside Kanékés

$11 \quad 02 \quad 63$ Panyerangan

O5 05

o4 05 - Rancakondang: see

Cirancakondang

12 o3 - Sirah Cicakal: see Cicakal

Girang

O2 $05 \quad 64$ Sorokokod

$05 \quad 01$

a Sirah Dayeuh/Sirahdayeuh and other dangka hamlets are mentioned in pantun stories, such as in Paksi Keuling (Pleyte 1912: 417). 